\title{
Statistical Analyses and Geotechnical Evaluation of Nubia Sandstone, Golden Triangle Area, Egypt
}

\author{
Hesham Ahmed Hussein Ismaiel, Mohamed Mohamed Askalany, Ali Ismail Ali* \\ Department of Geology, Faculty of Science, South Valley University, Qena, Egypt \\ Email: ^Ali.Ismail2@sci.svu.edu.eg
}

How to cite this paper: Ismaiel, H. A. H., Askalany, M. M., \& Ali, A. I. (2021). Statistical Analyses and Geotechnical Evaluation of Nubia Sandstone, Golden Triangle Area, Egypt. Journal of Geoscience and Environment Protection, 9, 46-60.

https://doi.org/10.4236/gep.2021.911004

Received: October 10, 2021

Accepted: November 13, 2021

Published: November 16, 2021

Copyright $\odot 2021$ by author(s) and Scientific Research Publishing Inc. This work is licensed under the Creative Commons Attribution International License (CC BY 4.0).

http://creativecommons.org/licenses/by/4.0/ (c) (i) Open Access

\begin{abstract}
Great efforts had been made to use indirect non-destructive tests in the geotechnical evaluation of rocks, especially sandstones, employing different empirical equations. However, most of these equations have been derived from hard and compacted sandstones data; therefore, the focus of this research is on weak and weakly compacted sandstones, aiming firstly to obtain empirical equations for estimating their characteristics, secondly to demonstrate and visualize the correlations between the studied variables, and finally to cluster the studied samples based on their characteristics. To attain these aims, twenty oriented block samples were collected from Nubia sandstone, central Eastern Desert, Golden Triangle area, Egypt. These samples were prepared and tested according to standard test methods, including uniaxial compressive strength (UCS), Brazilian tensile strength (BTS), Schmidt rebound number (SRN), porosity $(n)$, bulk density $(\rho)$, and ultrasonic P-wave velocity (UPV). The loss on ignition (LOI) was also employed as a physicochemical test for classifying the studied samples and indicating pores filling materials. The results revealed that these sandstones are characterized mainly by high $n$, low $\rho$, and low UPV values and these give an indication of weakly compacted and weakly cemented sandstone with shallow burial diagenetic conditions. Based on UCS and elastic modulus values, these sandstones are mainly classified as very low strength and highly yielding rocks. The results of regression analysis show satisfactory correlations between physical and mechanical characteristics, indicating the suitability of obtained empirical equations to deduce these properties. Principal component analysis revealed that the LOI, BTS, SRN, and USC have a positive correlation to each other and weakly correlated with $\rho$ and UPV, which positively correlated to each other and negatively correlated to $n$. The results of agglomerative hierarchical clustering revealed that the studied samples can group into three main clusters depending on their USC, LOI, and $n$ values.
\end{abstract}




\section{Keywords}

Geotechnical Evaluation, Empirical Equations, Statistical Analyses, Nubia Sandstone, Non-Destructive Test

\section{Introduction}

Significant efforts had been made to use indirect non-destructive tests instead of direct destructive tests in geotechnical applications, such as tunnels, dams, rock excavation or drilling, roads, slope stability assessment, and building. This is due to the direct destructive tests, such as the unconfined compressive strength (UCS) test, which are mostly overworked, time consumed and more expensive, as it requires special sample preparation and depends on rigorous standards (Ceryan et al., 2013; Ozcelik, Bayram, \& Yasitli, 2013).

Moreover, these direct tests are mostly not suitable for weathered rocks, friable, jointed, foliated, and laminated rocks (Mishra \& Basu, 2012). It also may not be possible in the oil industry (Garia et al., 2019) and the historical building stones evaluation (Dan et al., 2010). Therefore, indirect non-destructive tests are frequently employed to obtain empirical equations to estimate the mechanical properties of rocks (Minaeian \& Ahangari, 2013). Ultrasonic P-wave velocity (UPV) test for example is one of the essential non-destructive tests, which is employed to investigate some properties of rocks, such as degree of rock weathering (Schmidt, 1951), tensile strength (Hosseini \& Shirin, 2015), UCS (Kurtulus et al., 2018), elastic properties (Abdullah et al., 2019), slake durability index (Hosseini, 2016), and the physical properties of rocks (Kurtuluş et al., 2016).

Numerous empirical equations have been obtained for estimating the geotechnical and physical properties of sedimentary rocks "especially sandstones" employing different indirect tests (Table 1). Most of these equations have been derived from hard and compacted sandstone data. Moreover, (Garia et al., 2019) concluded that the empirical equations derived by various researchers are valid only to the data set for which the relationship is derived, because of the chemical and mineralogical composition, pores geometry, grain size, cementing material not considered when evaluating these equations. For this reason, the loss on ignition (LOI) at high temperature $\left(1000^{\circ} \mathrm{C}\right)$ is employed as a physicochemical test in this work for indicating the nature of pores filling materials, which increase the strength of weakly compacted (shallow burial) sandstones and reduce their porosity and permeability. The LOI values are greatly influenced by volatiles such as sulfur, carbon dioxide, chlorine, and lattice water that forms the pore filling carbonate minerals (calcite and dolomite), salts, sulfates minerals (Gypsum and anhydrite), and clay minerals (Dabrio et al., 2004). The LOI determination is simple, inexpensive, and faster than the other geochemical and petrographical analyses, so that the LOI test can be very useful for obtaining empirical equations, understanding the mechanical behavior of the weak sandstones, and classifying the studied sandstone. 
Table 1. Equations for predicting some physical and mechanical prosperity of sandstones and other sedimentary rocks from several areas in the world with their references, input data, units, and regression coefficient $(\mathrm{R})$.

\begin{tabular}{|c|c|c|c|c|}
\hline Input data & Reference & Equation & Unit & $\mathrm{R}$ \\
\hline UPV \& $n \%$ & (Soroush et al., 2011) & $n=-7.415 \ln (\mathrm{UPV})+64.96$ & $\mathrm{~m} / \mathrm{s}$ & 0.78 \\
\hline UPV \& $\rho$ & (Soroush et al., 2011) & $\rho=-2 \times 10^{-8} \mathrm{UPV}^{2}+0.0002 \mathrm{UPV}+1.93$ & $\mathrm{~g} / \mathrm{cm}^{3}, \mathrm{~m} / \mathrm{s}$ & 0.71 \\
\hline \multirow{5}{*}{ UPV \& UCS } & (Kurtuluş et al., 2016) & $\mathrm{UCS}=8.1^{-6} \mathrm{UPV}^{2-0.024} \mathrm{UPV}+31.92$ & $\mathrm{MPa}, \mathrm{m} / \mathrm{s}$ & 0.89 \\
\hline & (Kahraman, 2007) & $\mathrm{UCS}=9.95 \mathrm{UPV}^{1.21}$ & $\mathrm{MPa}, \mathrm{km} / \mathrm{s}$ & 0.69 \\
\hline & (Sharma \& Singh, 2008) & $\mathrm{UCS}=0.0642 \mathrm{UPV}-117.99$ & \multirow{3}{*}{$\mathrm{MPa}, \mathrm{m} / \mathrm{s}$} & 0.9 \\
\hline & (Chary et al., 2006) & $\mathrm{UCS}=0.0144 \mathrm{UPV}-24.856$ & & 0.71 \\
\hline & (Altindag, 2012) & $\mathrm{UCS}=12.746 \mathrm{UPV}^{1.194}$ & & 0.79 \\
\hline UPV \& TS & \multirow{2}{*}{ (Kurtuluş et al., 2016) } & $\mathrm{TS}=0.008 \mathrm{UPV}+3.84$ & \multirow{2}{*}{$\mathrm{MPa}, \mathrm{m} / \mathrm{s}$} & 0.78 \\
\hline UPV \& SRN & & $\mathrm{SRN}=0.006 \mathrm{UPV}+9.52$ & & 0.8 \\
\hline SRN \& UCS & (Gökçeoğlu, 1996) & $\mathrm{UCS}=0.0001 \mathrm{SRN}^{3.2658}$ & $\mathrm{MPa}$ & 0.84 \\
\hline \multirow{2}{*}{$n \% \& \mathrm{UCS}$} & (Palchik, 1999) & $\mathrm{UCS}=74.4 \mathrm{e}^{(-0.04 n)}$ & \multirow{2}{*}{$\mathrm{MPa}$} & 0.78 \\
\hline & (K1lıç \& Teymen, 2008) & $\mathrm{UCS}=147.16 \mathrm{e}^{(-0.0835 n)}$ & & 0.93 \\
\hline \multirow{2}{*}{ E \& UCS } & (Bradford et al., 2007) & $\mathrm{UCS}=2.28+4.1089 \mathrm{E}$ & UCS MPa, E (GPa) & --- \\
\hline & (Lacy, 1997) & $\mathrm{UCS}=0.2787 \mathrm{E}^{2}+2.4582 \mathrm{E}$ & E (Mpsi), UCS (kpsi) & 0.84 \\
\hline
\end{tabular}

The main aims of this study are first to obtain empirical equations for estimating the physical and mechanical properties of weakly compacted and weakly cemented sandstone employing Schmidt rebound number (SRN), porosity $(n)$, bulk density $(\rho)$, LOI, and UPV measurements. Secondly, to understand and visualize the correlation between the tested variables using the principal component analysis (PCA). Thirdly, to group the studied sandstone samples depending on their physical and mechanical properties, using cluster analysis (CA).

The present research has a general significance, because most previous workers conduct their studies on hard and compacted sandstone. Besides, Nubia sandstone has a high variability of sandstone and could represent the most suitable bedrock of buildings and infrastructures of industrial, tourism, and new urban zones in the studied area (Figure 1(a)).

\section{Geological Setting and Location}

Nubia sandstone (Taref sandstone Formation) is the most widely distributed sandstone unit having a considerable thickness in the Golden Triangle area, central Eastern Desert, Egypt. This area is covered in its western part by clastic sedimentary rock successions ranging in age from Upper Cretaceous to Quaternary (Said, 1981) (Figure 1(b)). The Nubia sandstone lies unconformably on the Precambrian basement complex and forms the basal unit of the platform sediment succession. In the study area, it composed mainly of massive and cross-bedded sandstone, which was divided into three, four, or five lithologically distinct Facies (Abbass, 1962; Abdel-Wahab \& Turner, 1991; Ghanem et al., 1970; Van Houten et al., 1984; Mansour, 1985; Ward \& McDonald, 1979) with different nomenclatures and boundaries. 


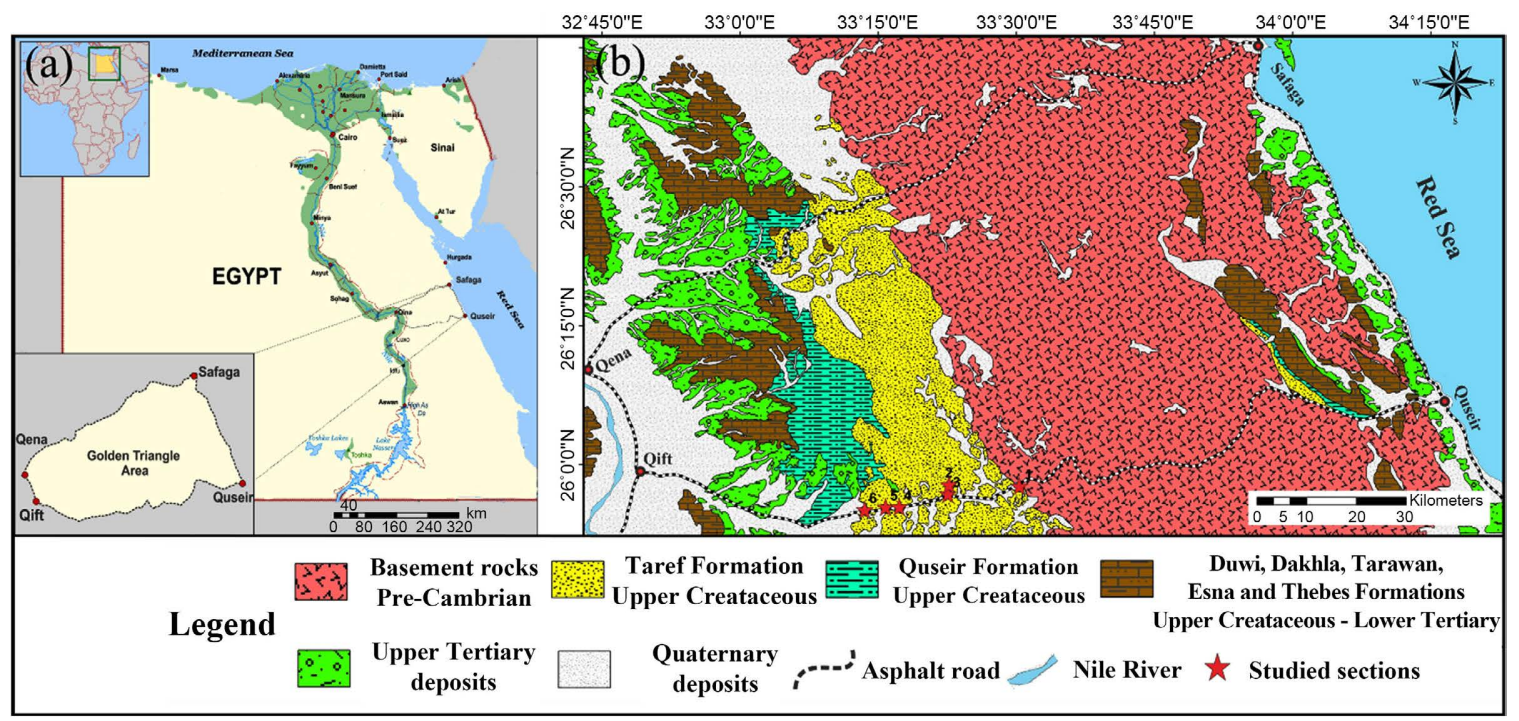

Figure 1. (a) Location map and (b) Geological map (Conoco, 1987) of the study area (the Golden Triangle area).

According to Van Houten et al. (1984) Taref sandstone Formation consists mainly of massive and cross-bedded sandstone and can be divided into three lithologically distinct Facies. The lower Facies consists of a succession trough cross-bedded, fining-upward sequences composed of kaolinite-rich, very coarse-grained quartzose sandstone (60 - $70 \mathrm{~m}$ thick). The middle Facies consists of thin-bedded, generally finer-grained deposits (15 to $20 \mathrm{~m}$ thick), overlain by three parallel-bedded coarsening-upward sequences (5 to $18 \mathrm{~m}$ thick) begin with laminated greenish-gray claystone and pass upward through silty clay into ripple- and cross-bedded, fine-grained sandstone. The upper Facies consists of uniform large-scale, tabular-planar-cross-bedded member ( 15 to $30 \mathrm{~m}$ thick), overlain by tens meters of ripple-bedded siltstone and mudstone, which grades upward into Quseir Formation (Van Houten et al., 1984).

\section{Materials and Methods}

\subsection{Materials}

A total of twenty oriented block sandstone samples were selected based on preliminary stratigraphic observations to ensuring the representation of each litho-type in Nubia sandstone. Macroscopic descriptions of petrographic features of the collected samples were listed in Table 2. A representative sample comprises three specimens of cylindrical and disc-shaped were prepared according to ISRM (Bieniawski \& Hawkes, 1978; Fairhurst \& Hudson, 1999). The axes of specimens were chosen perpendicular to the bedding planes. The average length to diameter ratios (L/D) is 2.24 and 0.50 for cylindrical and disc-shaped specimens, respectively. Their average diameter is $4.33 \mathrm{~cm}$.

\subsection{Methods}

In this work, the $\rho$ and $n$ values were determined by saturation and caliper technique, according to ISRM (Brown, 1981). The LOI values were determined 
Table 2. Macroscopic description of petrographic features for the collected block samples.

\begin{tabular}{|c|c|c|c|}
\hline Block ID & Facies & Macroscopic description of petrographic features & Litho-type \\
\hline U4 & \multirow{4}{*}{ Upper } & $\begin{array}{l}\text { Light brown bedded, oolitic fine sandstone, inter-bedded with siltstone, bonded with clay matrix } \\
\text { and calcareous cement }\end{array}$ & \multirow{4}{*}{ Wacke } \\
\hline U3 & & Dark brown massive fine sandstone, bonded with clay matrix, iron oxides, and calcareous cements & \\
\hline $\mathrm{U} 2$ & & $\begin{array}{l}\text { Light brown bedded fine sandstone, inter-bedded with siltstone, bonded with clay matrix and } \\
\text { calcareous cement }\end{array}$ & \\
\hline $\mathrm{U} 1$ & & $\begin{array}{l}\text { Light to dark brown, oolitic fine sandstone, inter-bedded with siltstone, bonded with clay matrix } \\
\text { and calcareous cement }\end{array}$ & \\
\hline M6 & \multirow{6}{*}{ Middle } & $\begin{array}{l}\text { Yellow-dark brown bedded medium sandstone, poorly cemented with silica and iron oxide } \\
\text { cements }\end{array}$ & \multirow{6}{*}{-Arenite } \\
\hline M5 & & $\begin{array}{l}\text { Brown-grey fine to medium sandstone, well cemented by iron oxides and very frequent calcareous } \\
\text { cement concentration }\end{array}$ & \\
\hline M4 & & White massive fine to medium sandstone, poorly cemented with silica cement & \\
\hline M3 & & $\begin{array}{l}\text { Brown-light brown bedded, fine to medium grained sandstone, well cemented by iron oxides } \\
\text { cement }\end{array}$ & \\
\hline M2 & & $\begin{array}{l}\text { Yellow violet bedded medium sandstone, well cemented with silica iron oxide and calcareous } \\
\text { cements }\end{array}$ & \\
\hline M1 & & Dark brown fine sandstone, well cemented by iron oxides cement & \\
\hline L10 & \multirow{10}{*}{ Lower } & $\begin{array}{l}\text { Yellow-dark brown bedded medium sandstone, poorly cemented with silica and iron oxides } \\
\text { cements }\end{array}$ & \multirow[t]{2}{*}{ Arenite } \\
\hline L9 & & Yellow fine to medium sandstone, poorly cemented with iron oxides cement & \\
\hline L8 & & $\begin{array}{l}\text { Mottled creamy white-reddish brown fine sandstone, very frequent iron oxide nodules and clay } \\
\text { pockets, bonded with clay matrix and iron oxides cement }\end{array}$ & Wacke \\
\hline L7 & & Light brown bedded fine to medium sandstone, poorly cemented by iron oxides cement & \multirow{6}{*}{ Arenite } \\
\hline L6 & & $\begin{array}{l}\text { Yellow-light red bedded coarse to medium sandstone, weakly cemented by silica and iron oxides } \\
\text { cements }\end{array}$ & \\
\hline L5 & & $\begin{array}{l}\text { Dark violet-yellow bedded fine to medium sandstone, well cemented by iron oxides and silica } \\
\text { cements }\end{array}$ & \\
\hline L4 & & $\begin{array}{l}\text { Dark violet-white bedded fine to medium sandstone, well cemented by iron oxides and silica } \\
\text { cements }\end{array}$ & \\
\hline L3 & & $\begin{array}{l}\text { Yellow - dark grey bedded coarse to medium sandstone, poorly cemented with Iron oxides and } \\
\text { silica cements }\end{array}$ & \\
\hline $\mathrm{L} 2$ & & $\begin{array}{l}\text { Reddish brown bedded medium to coarse sandstone, with coarse grained small lenses, poorly } \\
\text { cemented by Iron oxides and silica cements }\end{array}$ & \\
\hline L1 & & $\begin{array}{l}\text { Mottled yellow-violet fine to coarse sandstone, interbedded with siltstone, very frequent iron } \\
\text { oxides nodules, bonded with clay matrix and iron oxide cement }\end{array}$ & Wacke \\
\hline
\end{tabular}

according to Dabrio et al. (2004). The UPV measurements are performed using V-Meter ${ }^{\mathrm{TM}}$ (Mark III) ultrasonic tester with a $54 \mathrm{kHz}$ transducer, depending on ISRM standard (Aydin, 2014). UCS of the studied samples was measured using Impact ${ }^{\mathrm{TM}}$ loading machine (1000 $\mathrm{KN}$, maximum load), according to ISRM (Fairhurst \& Hudson, 1999). The load rate was $0.15 \mathrm{~mm} / \mathrm{min}$ for most of the 
tested specimens. The tangential elastic modulus at $50 \%$ strain $\left(\mathrm{E}_{\mathrm{t} 50}\right)$ was measured and calculated for each specimen according to ISRM (Fairhurst \& Hudson, 1999). The Brazilian test was carried out according to ISRM (Bieniawski \& Hawkes, 1978), using Matest ${ }^{\mathrm{TM}}$ multi-tester (50 KN, maximum load). The Schmidt hammer test was performed directly at several points on each block sample according to ISRM (Aydin, 2009). All tests were conducted in the engineering geology laboratory of South Valley University, Qena, Egypt.

\section{Results and Discussions}

\subsection{Physical and Mechanical Results}

The results of the physical and mechanical characterization are listed in Table 3.

Table 3. The results of physical and mechanical properties, LOI, and their descriptive statics.

\begin{tabular}{|c|c|c|c|c|c|c|c|c|c|c|c|c|}
\hline Sample & Facies & $\begin{array}{l}\text { UPV } \\
(\mathrm{m} / \mathrm{s})\end{array}$ & $\begin{array}{c}\rho \\
\left(\mathrm{g} / \mathrm{cm}^{3}\right)\end{array}$ & $\begin{array}{c}n \\
(\%)\end{array}$ & $\begin{array}{l}\text { LOI } \\
(\%)\end{array}$ & $\begin{array}{c}\text { Log } \\
(\mathrm{LOI})\end{array}$ & $\begin{array}{c}\text { LOI } \\
\text { G. }\end{array}$ & SRN & $\begin{array}{c}\text { UCS } \\
(\mathrm{MPa})\end{array}$ & $\begin{array}{c}\mathrm{E}_{\mathrm{t} 50} \\
(\mathrm{GPa})\end{array}$ & $\begin{array}{c}\text { BTS } \\
(\mathrm{MPa})\end{array}$ & Litho-type \\
\hline $\mathrm{U} 4$ & \multirow{4}{*}{ Upper } & 1516.70 & 1.83 & 28.86 & 3.35 & 0.53 & G3 & 30.23 & 13.66 & 1.85 & 1.02 & \multirow{4}{*}{ Wacke } \\
\hline U3 & & 3683.10 & 2.42 & 1.47 & 16.57 & 1.22 & G3 & 50.67 & 94.81 & 14.16 & 11.53 & \\
\hline $\mathrm{U} 2$ & & 1295.40 & 1.84 & 27.88 & 4.11 & 0.61 & G3 & 27.08 & 12.85 & 1.28 & 1.51 & \\
\hline U1 & & 1753.10 & 1.98 & 22.52 & 12.44 & 1.09 & G3 & 30.33 & 19.31 & 1.64 & 1.91 & \\
\hline M6 & \multirow{6}{*}{ Middle } & 2917.20 & 1.88 & 20.00 & 2.55 & 0.41 & G2 & 34.44 & 24.73 & 2.54 & 2.06 & \multirow{6}{*}{ Arenite } \\
\hline M5 & & 2350.80 & 1.95 & 23.08 & 0.65 & -0.19 & G2 & 33.00 & 21.50 & 2.14 & 2.48 & \\
\hline M4 & & 2107.40 & 1.86 & 29.41 & 0.20 & -0.70 & $\mathrm{G} 1$ & 30.52 & 16.17 & 1.93 & 1.56 & \\
\hline M3 & & 2234.50 & 1.94 & 24.12 & 1.50 & 0.18 & G2 & 31.47 & 17.21 & 2.03 & 1.57 & \\
\hline M2 & & 2574.30 & 1.85 & 28.14 & 0.08 & -1.10 & G1 & 31.64 & 14.41 & 2.08 & 2.41 & \\
\hline M1 & & 2286.90 & 1.98 & 25.50 & 1.69 & 0.23 & G2 & 30.62 & 14.02 & 2.67 & 1.43 & \\
\hline L10 & \multirow{10}{*}{ Lower } & 2614.30 & 2.06 & 20.00 & 0.58 & -0.24 & $\mathrm{G} 2$ & 27.92 & 12.19 & 2.16 & 1.22 & \multirow{2}{*}{ Arenite } \\
\hline L9 & & 2457.80 & 1.98 & 23.01 & 0.55 & -0.26 & $\mathrm{G} 2$ & 29.64 & 12.28 & 2.49 & 1.41 & \\
\hline L8 & & 2667.10 & 2.31 & 12.53 & 4.58 & 0.66 & G3 & 28.91 & 14.93 & 1.17 & 1.48 & Wacke \\
\hline L7 & & 2229.50 & 1.97 & 24.48 & 0.96 & -0.02 & G2 & 26.60 & 12.03 & 3.34 & 0.88 & \multirow{6}{*}{ Arenite } \\
\hline L6 & & --- & 1.92 & 20.00 & 1.95 & 0.29 & $\mathrm{G} 2$ & 22.00 & --- & --- & --- & \\
\hline L5 & & 2376.10 & 1.97 & 22.37 & 0.82 & -0.09 & $\mathrm{G} 2$ & 28.86 & 11.66 & 2.79 & 1.73 & \\
\hline $\mathrm{L} 4$ & & 2355.70 & 1.93 & 25.04 & 0.70 & -0.15 & G2 & 27.00 & 9.69 & 1.96 & 1.20 & \\
\hline L3 & & 2407.90 & 1.93 & 22.62 & 1.75 & 0.24 & G2 & 23.14 & 5.57 & 0.70 & 0.74 & \\
\hline $\mathrm{L} 2$ & & 2943.70 & 1.98 & 18.17 & 1.49 & 0.17 & G2 & 26.31 & 9.56 & 2.59 & 1.91 & \\
\hline $\mathrm{L} 1$ & & 2944.30 & 2.29 & 12.55 & 4.75 & 0.68 & G3 & 36.32 & 23.71 & 3.94 & 3.62 & Wacke \\
\hline \multicolumn{2}{|c|}{ Min. } & 1295.40 & 1.83 & 1.47 & 0.08 & - & - & 23.14 & 5.57 & 0.70 & 0.74 & - \\
\hline \multicolumn{2}{|c|}{ Max. } & 3683.10 & 2.41 & 29.41 & 16.57 & - & - & 50.67 & 94.81 & 14.16 & 11.53 & - \\
\hline \multicolumn{2}{|c|}{ Mean } & 2406.10 & 1.10 & 21.70 & 3.12 & - & - & 30.77 & 18.97 & 2.81 & 2.12 & - \\
\hline \multicolumn{2}{|c|}{ Std. dev. } & 539.28 & 0.17 & 6.79 & 4.32 & - & - & 5.71 & 19.00 & 2.85 & 2.36 & - \\
\hline \multicolumn{2}{|c|}{ KMO } & 0.66 & 0.72 & 0.69 & 0.79 & - & - & 0.82 & 0.80 & 0.85 & 0.92 & Total $(0.786)$ \\
\hline
\end{tabular}


It is obvious that the average $\mathrm{n}$ of the middle Facies samples is mainly higher than that of the lower and the upper Facies, and their average values are $25.04 \%$, $20.08 \%$, and $20.18 \%$, successively. The $\rho$ values are in the range of $1.84 \mathrm{~g} / \mathrm{cm}^{3}$ to $2.29 \mathrm{~g} / \mathrm{cm}^{3}$ for the studied samples, their average values are 2.03, 1.91, and 2.01 $\mathrm{g} / \mathrm{cm}^{3}$ for lower, middle, and upper Facies, successively. Anyway, the studied samples are mainly characterized by low density and high porosity; these give an indication of weakly compacted and weakly cemented sandstones with a shallow burial diagenetic condition.

The integration between LOI, litho-types, and macroscopic description of the studied samples revealed that the LOI values (Table 3) are higher in sandstone samples which characterized by clay or carbonate minerals cement (low silica content samples), these samples include L1, L8, and all samples of upper Facies (U1, U2, U3, and U4). The common logarithmic values (Log) of LOI are used to classify the studied sample into three groups; the first group (G1), the second group (G2) and the third group (G3), these groups have the following Log (LOI) values; "less than -0.5 ", “ -0.5 to +0.5 " and "more than +0.5 ", respectively. Based on this classification, all wacke litho-type samples belong to G3, while all arenite litho-type samples belong to G2, except the high silica content samples (low LOI) belong to G1.

The UPV values of the studied samples are mainly low and ranging from 1295.4 to $3683.1 \mathrm{~m} / \mathrm{s}$. Their average values are $2555.2,2411.9$, and $2062.1 \mathrm{~m} / \mathrm{s}$ for lower, middle, and upper Facies, successively. The UCS values are in the range of 5.57 and $94.81 \mathrm{MPa}$, while Et50 values are in the range of 0.7 to $14.2 \mathrm{GPa}$. Based on these values, the tested samples are mainly classified as very low strength rocks (Bieniawski, 1973) with a very low Et50 (Highly yielding), except the U3 sample which is classified as medium strength rock. The BTS values are mainly low and extend from 0.74 to $11.53 \mathrm{MPa}$. The SRN values are varying between 23.14 and 50.67 .

\subsection{Statistical Analysis Results}

\subsubsection{Regression Analysis}

The linear regression between $n$ and $\rho$ shows a high regression coefficient $\left(\mathrm{R}^{2}=\right.$ 0.87 ), the linear regression between UPV and $n$ of all samples shows a high regression coefficient $\left(\mathrm{R}^{2}=0.64\right)$ and this value increased to be 0.974 for $\mathrm{G} 1$ samples and 0.825 for G2 samples (Figure 2) when each group correlated separately.

The relationship of LOI with UPV and $n$ can be explained by the truth of the LOI values of sandstone, especially surface sandstone, positively correlated with pores filling materials such as carbonates, sulfates, and clay. These pores filling materials decrease the porosity of sandstone in a dramatic way, and additionally, it increases the strength of uncompacted sandstones.

The linear regression between UPV and $\rho$ does not show a high regression coefficient (0.47), because the relation between UPV and $\rho$ depends on numerous factors such as rock strength and integrity, effective stress, mineral composition, granular structure, cementation, porosity, lithology, saturation, micro-cracks, 


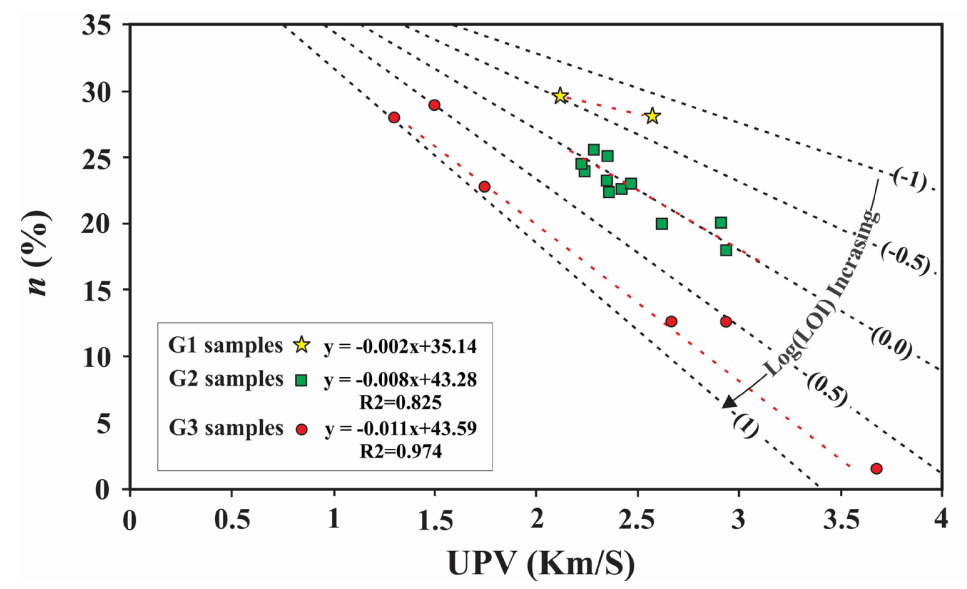

Figure 2. Diagram showing the LOI groups of the studied sample and the correlation between their UPV and $n$ values.

fluid pressure, depth of burial, geological age, and many other factors (Horsfall et al., 2017). A moderate correlation $\left(\mathrm{R}^{2}=0.346\right)$ is observed between UPV and UCS, so that the UPV measurement alone does not suitable to predict the strength and deformability of weakly compacted and weakly cemented sandstone, while the SRN has a very high regression coefficient $\left(\mathrm{R}^{2}=0.94\right)$ with $\mathrm{UCS}, \mathrm{BTS}\left(\mathrm{R}^{2}=\right.$ $0.78)$, and $E_{t 50}\left(R^{2}=0.85\right)$. There is also a high regression of LOI with UCS $\left(R^{2}=\right.$ $0.62)$ and $n \%\left(\mathrm{R}^{2}=0.59\right)$, indicating the suitability of these empirical equations to deduce these properties. The values of these properties are represented in correlation point diagrams (Figure 3). The most suitable empirical equations with the highest regression coefficient $\left(\mathrm{R}^{2}\right)$ are obtained and listed in Table 4.

\subsubsection{Principal Components Analysis}

To conduct PCA, the Kaiser-Meyer-Olkin (KMO) measurement is firstly performed (Table 3 ) to assess sample adequacy. The total KMO value is 0.786 . This value gives an indication of sampling adequacy. Secondly, descriptive statics of the studied variables are calculated, these include mean, standard deviation, minimum and maximum, their values are also listed in Table 3. Finally, the variables correlation matrix is determined (Table 5) to deduce eigenvalues (Table 6), eigenvectors and factor loadings.

A two-component solution was suggested, based on the correlation between variables and factors "components matrix" (Table 7). The first principal component (F1), which clarifies the largest part of the total variance, has an eigenvalue of 6.17 and represents $77.14 \%$ of the total variance. The second principal component (F2) has a variance of 0.94 and accounts for a further $11.77 \%$ of the variance. F1 positively correlated with all variables and negatively correlated only with $n$, while F2 is positively correlated with both $\rho$ and UPV, and negatively correlated with the other variables.

The principal components plot (Figure 4(a)) helps visualize the relations between the studied variables. These variables were illustrated as arrows, and the position to each other explains the relation between them. 



Figure 3. Regression diagrams between physical and mechanical properties of the studied sample. 
Table 4. The proposed equations for predicting some physical and mechanical prosperity with their input data, units, and regression coefficient $(\mathrm{R})$.

\begin{tabular}{|c|c|c|c|}
\hline Input data & \multicolumn{2}{|c|}{ Empirical equation } & Regression \\
\hline \multirow{4}{*}{$\mathrm{UPV}(\mathrm{m} / \mathrm{s}) \& n(\%)$} & All samples & $n(\%)=-10.089(\mathrm{UPV})+45.94$ & 0.641 \\
\hline & G1 Samples & $n(\%)=-0.002(\mathrm{UPV})+35.14$ & --- \\
\hline & G2 Samples & $n(\%)=-0.008(\mathrm{UPV})+43.28$ & 0.825 \\
\hline & G3 Samples & $n(\%)=-0.011(\mathrm{UPV})+43.59$ & 0.974 \\
\hline $\mathrm{UPV}(\mathrm{m} / \mathrm{s}) \& \rho\left(\mathrm{g} / \mathrm{cm}^{3}\right)$ & \multicolumn{2}{|c|}{$\rho=0.2094(\mathrm{UPV})+1.4935$} & 0.468 \\
\hline $\mathrm{UPV}(\mathrm{m} / \mathrm{s}) \& \mathrm{UCS}(\mathrm{MPa})$ & \multicolumn{2}{|c|}{$\mathrm{UCS}=20.72(\mathrm{UPV})-30.899$} & 0.346 \\
\hline SRN \& UCS (MPa) & \multicolumn{2}{|c|}{$\mathrm{UCS}=0.0002(\mathrm{SRN})^{3.3709}$} & 0.944 \\
\hline $\mathrm{SRN} \& \mathrm{E}_{\mathrm{t} 50}(\mathrm{GPa})$ & \multicolumn{2}{|c|}{$\mathrm{E}_{\mathrm{t} 50}=0.4409(\mathrm{SRN})-10.755$} & 0.782 \\
\hline SRN \& BTS (MPa) & \multicolumn{2}{|c|}{$\mathrm{BTS}=0.0917 \mathrm{e}^{0.0955(\mathrm{SRN})}$} & 0.852 \\
\hline$n(\%) \& \mathrm{UCS}(\mathrm{MPa})$ & \multicolumn{2}{|c|}{$\mathrm{UCS}=-26.472 \ln (n)+97.264$} & 0.864 \\
\hline LOI (\%) \& UCS (MPa) & \multicolumn{2}{|c|}{$\mathrm{UCS}=3.4616(\mathrm{LOI})+8.1553$} & 0.619 \\
\hline LOI (\%) \& $n(\%)$ & \multicolumn{2}{|c|}{$n(\%)=27.881 \mathrm{e}^{-0.119 \text { (LOI) }}$} & 0.589 \\
\hline
\end{tabular}

Table 5. Correlation matrix between the studied variables.

\begin{tabular}{ccccccccc}
\hline Variables & UPV & $\boldsymbol{\rho}$ & $\boldsymbol{n}$ & LOI & SRN & UCS & E $_{\text {t50 }}$ & TS \\
\hline UPV & 1.000 & 0.688 & -0.801 & 0.256 & 0.588 & 0.588 & 0.646 & 0.644 \\
$\rho$ & 0.688 & 1.000 & -0.933 & 0.596 & 0.603 & 0.637 & 0.650 & 0.671 \\
$n$ & -0.801 & -0.933 & 1.000 & -0.661 & -0.680 & -0.744 & -0.742 & -0.773 \\
LOI & 0.256 & 0.596 & -0.661 & 1.000 & 0.689 & 0.787 & 0.697 & 0.760 \\
RN & 0.588 & 0.603 & -0.680 & 0.689 & 1.000 & 0.942 & 0.884 & 0.928 \\
UCS & 0.588 & 0.637 & -0.744 & 0.787 & 0.942 & 1.000 & 0.958 & 0.980 \\
E & 0.646 & 0.650 & -0.742 & 0.697 & 0.884 & 0.958 & 1.000 & 0.963 \\
TS & 0.644 & 0.671 & -0.773 & 0.760 & 0.928 & 0.980 & 0.963 & 1.000 \\
\hline
\end{tabular}

Table 6. Eigenvalues of correlation matrix.

\begin{tabular}{ccccccccc}
\hline Components & F1 & F2 & F3 & F4 & F5 & F6 & F7 & F8 \\
\hline Eigenvalue & 6.17 & 0.94 & 0.57 & 0.14 & 0.11 & 0.03 & 0.02 & 0.01 \\
Variability (\%) & 77.15 & 11.77 & 7.12 & 1.77 & 1.40 & 0.37 & 0.28 & 0.15 \\
Cumulative \% & 77.15 & 88.92 & 96.04 & 97.80 & 99.20 & 99.57 & 99.85 & 100.00 \\
\hline
\end{tabular}

Table 7. Correlations between variables and factors "component matrix".

\begin{tabular}{cccccc}
\hline Variables & F1 & F2 & F3 & F4 & F5 \\
\hline UPV & 0.736 & 0.571 & -0.305 & -0.170 & -0.088 \\
$\rho$ & 0.816 & 0.403 & 0.347 & 0.208 & 0.060 \\
$n$ & -0.897 & -0.359 & -0.218 & 0.052 & 0.013 \\
LOI & 0.780 & -0.389 & 0.446 & -0.177 & -0.082 \\
SRN & 0.909 & -0.229 & -0.208 & 0.187 & -0.204 \\
UCS & 0.954 & -0.254 & -0.114 & 0.000 & 0.019 \\
Et50 & 0.940 & -0.155 & -0.189 & -0.016 & 0.221 \\
TS & 0.965 & -0.179 & -0.131 & -0.016 & 0.053 \\
\hline
\end{tabular}






(a)

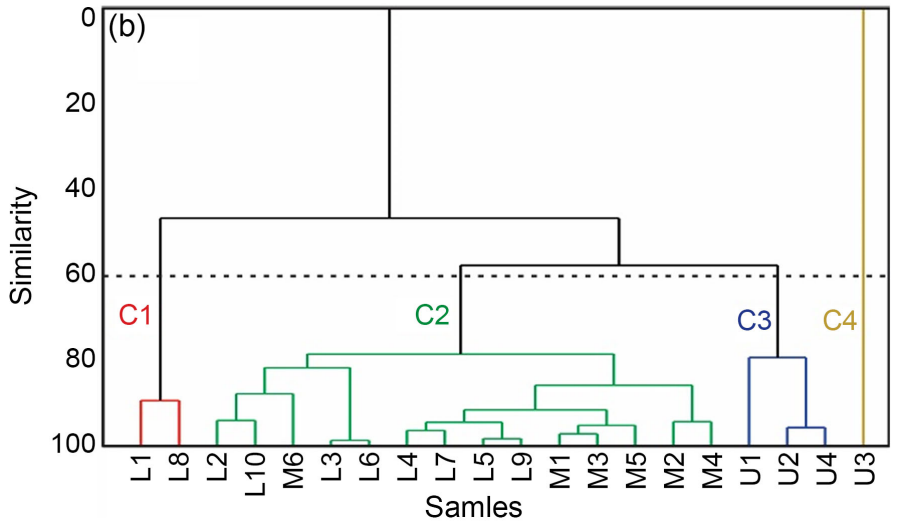

(b)

Figure 4. (a) Diagrams showing principal component analysis; (b) Cluster analyses with clusters based on the physical and mechanical properties of studied sandstones.

The arrows of LOI, $\mathrm{E}_{\mathrm{t} 50}, \mathrm{BTS}, \mathrm{SRN}$, and USC are pointing in the same direction, so they have a positive relation to each other, and the same for the arrows of $\rho$ and UPV. In contrast, the arrow of $n$ is pointing in the opposite direction of $\rho$ and UPV, so it exhibits a negative relation to them. The arrows of $n, \rho$, and UPV are stand semi-perpendicular to other variables, so there is a weak relation between them and other variables.

The studied samples depict as points and the coordinates within the diagram, in this multidimensional system are calculated via scores, which are based on the loadings of the components.

\subsubsection{Agglomerative Hierarchical Clustering}

The results of agglomerative hierarchical clustering (AHC) revealed that the studied samples could cluster into four clusters as shown in the dendrogram (Figure 4(b)). The PCA analyses (Figure 4(a)) help to deduce the factors controlling this classification. Cluster C1 comprises two samples of lower Facies (L1 and L8), the common factors for cluster $\mathrm{C} 1$ samples are relatively medium strength, combined with relatively high Log LOI and relatively low porosity. Cluster C2 com- 
prises the rest of Lower and all the Middle Facies samples. The common factors for cluster C2 samples are relatively medium strength, combined with relatively low LOI and relatively high porosity. Clusters C3 comprise all Upper Facies samples except one sample (U3) and its common factors are relatively medium strength, high porosity, and high LOI. While Cluster C4 comprises only one sample (U3), which has relatively high strength, low porosity, and high LOI.

\section{Conclusion}

Based on the experimental investigation and statistical analysis for physical and mechanical properties of weak Nubia sandstones, the following conclusions are drawn:

1) The studied samples are mainly characterized by low density and high porosity, and these give an indication of weak compaction and weak cementation with shallow burial diagenetic conditions.

2) LOI values are employed to group the studied samples into three groups, G1, G2 and G3. All wacke litho-type samples belong to G3, arenite litho-type samples belong to G2, while very high silica content samples belong to G1. This LOI grouping is very helpful to easily correlate the physical and mechanical properties of similar lithological sandstones with each other and to evaluate the nature of pores filling materials. LOI values are also highly correlated with UCS $\left(\mathrm{R}^{2}=0.62\right)$ and $n \%\left(\mathrm{R}^{2}=0.59\right)$.

3) The studied samples are mainly classified as very low strength rocks with low $\mathrm{E}_{\mathrm{t} 50}$ (Highly yielding).

4) Results of regression analysis showed satisfactory correlations between physical and mechanical characteristics, indicating the suitability of obtained empirical equations to deduce these properties.

5) The UPV measurement alone is not suitable to predict the strength and deformability of weakly compacted and weakly cemented sandstone, while the SRN values are more suitable and highly correlated with UCS $\left(\mathrm{R}^{2}=0.937\right)$, BTS $\left(\mathrm{R}^{2}=0.976\right)$ and $\mathrm{E}_{\mathrm{t} 50}\left(\mathrm{R}^{2}=0.944\right)$ values.

6) PCA results revealed that the LOI, BTS, SRN, and USC have a positive correlation to each other and weakly correlated with $\rho$ and UPV, which positively correlated to each other and negatively correlated to $n$. In addition, there is a weak relation of $n, \rho$ and UPV with other variables.

7) The results of AHC revealed that the studied samples cluster into four clusters depending on their USC, LOI, and $n \%$.

\section{Acknowledgements}

Sincere thanks to South Valley University, Qena, Egypt, for fully funding this research.

\section{Conflicts of Interest}

The authors declare no conflicts of interest regarding the publication of this paper. 


\section{References}

Abbass, H. L. (1962). A Monograph on the Egyptian Cretaceous Pelecypods. United Arab Republic, Ministry of Industry, Geological Survey and Mineral Research Department, Geological Museum.

Abdel-Wahab, A. A., \& Turner, P. (1991). Diagenesis of the Nubia Formation, Central Eastern Desert, Egypt. Journal of African Earth Sciences, 13, 343-358. https://doi.org/10.1016/0899-5362(91)90098-I

Abdullah, N. H., Sazaly, N. N., Awang, H., \& Hamid, N. H. (2019). Characterizing P-Wave Velocity and Elastic Properties of Sedimentary Rocks for Foundation of Building. Journal of Mechanical Engineering, 16, 199-210.

Altindag, R. (2012). Correlation between P-Wave Velocity and Some Mechanical Properties. The Journal of the Southern African Institute of Mining and Metallurgy, 112, 229-237.

Aydin, A. (2009). ISRM Suggested Method for Determination of the Schmidt Hammer Rebound Hardness: Revised Version. International Journal of Rock Mechanics and Mining Sciences, 46, 627-634. https://doi.org/10.1016/j.ijrmms.2008.01.020

Aydin, A. (2014). Upgraded ISRM Suggested Method for Determining Sound Velocity by Ultrasonic Pulse Transmission Technique. Rock Mechanics and Rock Engineering, 47, 255-259.

Bieniawski, Z. T. (1973). Engineering Classification of Jointed Rock Masses. Civil Engineer in South Africa, 15, 335-343.

Bieniawski, Z. T., \& Hawkes, I. (1978). Suggested Methods for Determining Tensile Strength of Rock Materials Part 1. Suggested Method for Determining Direct Tensile Strength. International Journal of Rock Mechanics and Mining Sciences, 15, 99-103. https://doi.org/10.1016/0148-9062(78)90003-7

Bradford, I. D. R., Fuller, J., Thompson, P. J., \& Walsgrove, T. R. (2007). Benefits of Assessing the Solids Production Risk in a North Sea Reservoir Using Elastoplastic Modelling. In SPE/ISRM Rock Mechanics in Petroleum Engineering (pp. 261-269). OnePetro.

Brown, E. T. (1981). Rock Characterisation, Testing and Monitoring. ISRM Suggested Methods (211 p). Oxford: Pergamon Press.

Ceryan, N., Okkan, U., \& Kesimal, A. (2013). Prediction of Unconfined Compressive Strength of Carbonate Rocks Using Artificial Neural Networks. Environmental Earth Sciences, 68, 807-819. https://doi.org/10.1007/s12665-012-1783-Z

Chary, K. B., Sarma, L. P., Lakshmi, K. J. P., Vijayakumar, N. A., Lakshmi, V. N., \& Rao, M. V. M. S. (2006). Evaluation of Engineering Properties of Rock Using Ultrasonic Pulse Velocity and Uniaxial Compressive Strength. In National Seminar on Non-Destructive Evaluation (pp. 379-385). Indian Society for Non-Destructive Testing Hyderabad Chapter.

Conoco (1987). Geological Map of Egypt, 1: 500,000, NG36NW-(ASYUT), NG36SW(LUXOR), NG36NE-(QUSEIR) and NG36SE-(GEBEL HAMATA). The Egyptian Petroleum Cooperation.

Dabrio, C. J., Santisteban, J. I., Mediavilla, R., Lo, E., Castan, S., Zapata, M. B. R., \& Jose, M. (2004). Loss on Ignition: A Qualitative or Quantitative Method for Organic Matter and Carbonate Mineral Content in Sediments. Journal of Paleolimnology, 32, 287-299. https://doi.org/10.1023/B:JOPL.0000042999.30131.5b

Dan, M. B., Přikryl, R., \& Török, Á. (Eds.). (2010). Materials, Technologies, and Practice in Historic Heritage Structures. Springer. https://doi.org/10.1007/978-90-481-2684-2

Fairhurst, C. E., \& Hudson, J. A. (1999). Draft ISRM Suggested Method for the Complete Stress-Strain Curve for Intact Rock in Uniaxial Compression. International Journal of 
Rock Mechanics and Mining Sciences, 36, 281-289.

Garia, S., Pal, A. K., Ravi, K., \& Nair, A. M. (2019). A Comprehensive Analysis on the Relationships between Elastic Wave Velocities and Petrophysical Properties of Sedimentary Rocks Based on Laboratory Measurements. Journal of Petroleum Exploration and Production Technology, 9, 1869-1881. https://doi.org/10.1007/s13202-019-0675-0

Ghanem, M., Zalata, A., Abd El-Razik, T., Mikhailov, I., Razraliaev, A., \& Mirtov, Y. (1970). Stratigraphy of the Phosphate-Bearing Cretaceous and Paleogene Sediments of the Nile Valley between Idfu and Qena (pp. 109-134). Studies on Some Mineral Deposits of Egypt, Geological Survey of Egypt.

Gökçeoğlu, C. (1996). Schmidt sertlik cekici kullanılarak tahmin edilen tek eksenli basınc dayanımı verilerinin guvenirligi uzerine bir degerlendirme. Jeoloji Mühendisliği Dergisi, $48,78-81$.

Horsfall, O. I., Uko, E. D. et al. (2017). Rock-Physics and Seismic-Inversion Based Reservoir Characterization of AKOS Field, Coastal Swamp Depobelt, Niger Delta, Nigeria. IOSR Journal of Applied Geology and Geophysics (IOSR-JAGG), 5, 59-67.

Hosseini, M. (2016). The Relationship between P-Wave Velocity and Slake Durability Index. International Journal of Geography and Geology, 5, 34-43.

https://doi.org/10.18488/journal.10/2016.5.2/10.2.34.43

Hosseini, M., \& Shirin, D. (2015). An Estimate of the Tensile Strength Based on P-Wave Velocity and Schmidt Hardness Rebound Number. International Journal of Geography and Geology, 4, 24-36. https://doi.org/10.18488/journal.10/2015.4.2/10.2.24.36

Kahraman, S. (2007). The Correlations between the Saturated and Dry P-Wave Velocity of Rocks. Ultrasonics, 46, 341-348. https://doi.org/10.1016/j.ultras.2007.05.003

Kılıç, A., \& Teymen, A. (2008). Determination of Mechanical Properties of Rocks Using Simple Methods. Bulletin of Engineering Geology and the Environment, 67, 237-244. https://doi.org/10.1007/s10064-008-0128-3

Kurtuluş, C., Sertçelik, F., \& Sertçelik, I. (2016). Correlating Physico-Mechanical Properties of Intact Rocks with P-Wave Velocity. Acta Geodaetica et Geophysica, 51, 571-582. https://doi.org/10.1007/s40328-015-0145-1

Kurtulus, C., Sertçelik, F., \& Sertçelik, I. (2018). Estimation of Unconfined Uniaxial Compressive Strength Using Schmidt Hardness and Ultrasonic Pulse Velocity. Tehnicki Vjesnik, 25, 1569-1574. https://doi.org/10.17559/TV-20170217110722

Lacy, L. L. (1997). Dynamic Rock Mechanics Testing for Optimized Fracture Designs. In The SPE Annual Technical Conference and Exhibition (pp. 23-36). Society of Petroleum Engineers. https://doi.org/10.2118/38716-MS

Mansour, A. M. (1985). Sedimentological Studies on the Nubia Sandstone, Red Sea, Egypt. Master's Thesis, Qena: South Valley University.

Minaeian, B., \& Ahangari, K. (2013). Estimation of Uniaxial Compressive Strength Based on P-Wave and Schmidt Hammer Rebound Using Statistical Method. Arabian Journal of Geosciences, 6, 1925-1931. https://doi.org/10.1007/s12517-011-0460-y

Mishra, D. A., \& Basu, A. (2012). Use of the Block Punch Test to Predict the Compressive and Tensile Strengths of Rocks. International Journal of Rock Mechanics and Mining Sciences, 51, 119-127. https://doi.org/10.1016/j.ijrmms.2012.01.016

Ozcelik, Y., Bayram, F., \& Yasitli, N. E. (2013). Prediction of Engineering Properties of Rocks from Microscopic Data. Arabian Journal of Geosciences, 6, 3651-3668. https://doi.org/10.1007/s12517-012-0625-3

Palchik, V. (1999). Influence of Porosity and Elastic Modulus on Uniaxial Compressive Strength in Soft Brittle Porous Sandstones. Rock Mechanics and Rock Engineering, 32, 
303-309. https://doi.org/10.1007/s006030050050

Said, R. (1981). The Geological Evolution of the River Nile. Springer-Verlag. https://doi.org/10.1007/978-1-4612-5841-4

Schmidt, E. (1951). A Non-Destructive Concrete Tester. Concrete, 59, 34-35.

Sharma, P. K., \& Singh, T. N. (2008). A Correlation between P-Wave Velocity, Impact Strength Index, Slake Durability Index and Uniaxial Compressive Strength. Bulletin of Engineering Geology and the Environment, 67, 17-22. https://doi.org/10.1007/s10064-007-0109-y

Soroush, H., Qutob, H., Oil, W., \& Me, T. (2011). Evaluation of Rock Properties Using Ultrasonic Pulse Technique and Correlating Static to Dynamic Elastic Constants. In The 2nd South Asian Geoscience Conference and Exhibition, (pp. 12-14). GEO India.

Van Houten, F. B., Bhattacharyya, D. P., \& Mansour, S. E. I. (1984). Cretaceous Nubia Formation and Correlative Deposits, Eastern Egypt: Major Regressive-Transgressive Complex (Natash Basin). Geological Society of America Bulletin, 95, 397-405. https://doi.org/10.1130/0016-7606(1984)95<397:CNFACD>2.0.CO;2

Ward, W. C., \& McDonald, K. C. (1979). Nubia Formation of Central Eastern Desert, Egypt-Major Subdivisions and Depositional Setting. American Association of Petroleum Geologists Bulletin, 63, 975-983.

https://doi.org/10.1306/2F9184AF-16CE-11D7-8645000102C1865D 